\title{
Antitrust Laws in the European Economic Community
}

\author{
Stefan A. Riesenfeld*
}

I

\begin{abstract}
CURRENT SIGNIFICANCE AND BACKGROUND OF THE NATIONAL LAWS AGAINST ANTI-COMPETITIVE PRACTICES
\end{abstract}

\section{A. Relative Roles of the Supranational and the National Regimes}

$\mathrm{T}_{\mathrm{i}}^{\mathrm{n}}$ He spectacular development of the European Common Market and its emergence as an integrated economic mechanism, shaped in large measure by the forces of competition, has placed new importance on legislation and institutional apparatus designed to protect the competitive processes against restraints and other measures or formations that trammel their effectiveness. Undoubtedly, the pivotal role in the picture is played today by the pertinent provisions of the Treaty Establishing the European Economic Community, ${ }^{1}$ especially articles $85-89,{ }^{2}$ and the recent first regulations for the application thereof. These regnlations were issued on February $6,1962,{ }^{3}$ in the wake of the momentous decision by the Council of January $14,1962,{ }^{4}$ to the effect that the second stage of the evolution of

* Emanuel S. Heller Professor of Law, University of California School of Law, Berkeley.

1298 U.N.T.S. 11 (1958). The treaty, often called the Treaty of Rome, was signed on March 25, 1957, and went into effect on January 1, 1958. For the background of the treaty and the genesis of the provisions protecting competition see Riesenfeld, The Protection of Competition, in 2 ANrerican Enterprise in tHe European Common Market: A LegaI Profine 197-342 (1960).

2 For an English translation from the original in the four official languages see Riesenfeld, op. cit. supra note 1 , at 200 .

3 Regulation No. 17: First regulation of the application of articles 85 and 86 of the treaty, issued on Feb. 6, 1962, 5 Journar Offictel des Conarunautés Européennes 204 (1962); SONDERBEITAGE zUNY BULLETIN DER EUROPÄISCHEN WIRTSCHAFTSGEMIEINSCHAFT, No. 2 (1962). For an excellent comment on the scope and effect of these regulations see van Hecke and Suetens, Le premier règlement européen sur les cartels et les monopoles, 77 JouRNaI des Trubunaux 361 (1962). Regulation No. 17 was implemented by Regulation No. 27: First regulation of the application of regulation No. 17 of the Council of Feb. 6, 1962, issued on May 3, 1962, 5 Journat OfFicIEL des Communadtés EuRopéenNes 1118 (1962). The Commission has issued an important Practical Guide for the Application of Articles 85 and 86 of the EEC Treaty and the Regulations Issued Thereunder, 2383/4/IV/62-D rev. The regulations have been the object of several written parliamentary questions. See Written Questions Nos. 96/1961 and 32/1962, 5 Journat OfFicier des Comanunautés Europíennes 1218, 1593 (1962); Europe, Aug. 7, 1962 (Daily Bull. No. 1335).

4 Decision of the Council of Jan. 14, 1962 concerning the entry into the second stage of the transitional period, 5 Journax Ofricial des Commounautés Européennes 164 (1962). 
the Common Market had been reached on January 1 of that year. Yet, it would be most unwise to presume that concern with the national laws is no longer necessary.

In order to substantiate, and elaborate on, this proposition some comments on the content and scope of articles 85-89 and the first regulations issued thereunder may be appropriate. The substantive law pertaining to anti-competitive practices is contained in the first two of these five articles, while the remaining ones supply the procedural implementation thereof. Article 85 concerns collective restraints by two or more enterprises, while article 86 deals with the abusive exploitation of a dominant position in the Common Market by one or more enterprises to the extent that commerce between member states may be affected. Because of its importance article 85 may be set out in full:

(1) Incompatible with the Common Market and prohibited are all agreements between enterprises, all decisions of associations of enterprises, and all concerted practices which are apt to affect adversely the commerce between member states and which have as their object or effect the prevention, restriction, or adulteration of competition within the Common Market, and especially those which consist in:

(a) fixing directly or indirectly the purchase or sales prices or other conditions of transacting business;

(b) limiting or controlling production, distribution, technical development, or investment;

(c) dividing the markets or sources of supply;

(d) applying unequal conditions for equivalent goods or services vis-àvis other contracting parties, thereby inflicting upon them a competitive disadvantage;

(e) conditioning the conclusion of contracts upon the acceptance by the other contracting parties of additional goods and services which, neither by their nature nor by commercial usage, have any connection with the objects of these contracts.

(2) The agreements or decisions prohibited according to this article are void.

(3) However, the provisions of section (1) may be declared inapplicable to: any agreement or category of agreements between enterprises, any decision or category of decisions of associations of enterprises, and any concerted practice or category of concerled practices, which contribute to the improvement of the production or distribution of commodities or to the promotion of technological or economic progress, while reserving an appropriate share of the resulting profit to the consumers and without:

(a) imposing on the enterprises involved any restrictions not indispensable for the attainment of these objectives, or

(b) enabling such enterprises to eliminate competition in respect of a substantial portion of the commodities involved. 
Article 87 required the Council of Ministers to issue appropriate regulations or directives for the application of the principles laid down in articles 85 and 86 , for the purpose in particular of:

(a) assuring the observance of the prohibitions set forth in articles 85 and 86, through the imposition of punitive and coercive fines;

(b) determining the particulars governing the application of article 85, subsection (3), having regard for the need both of assuring an effective supervision and, at the same time, of sinplifying administrative control to the greatest possible extent;

(c) specifying, if need be, the scope of application of articles 85 and 86 to the different sectors of the economy;

(d) defining the respective tasks of the Commission and of the Court of Justice in the application of the provisions envisaged in this article;

(e) defining the relations between the provisions of national law on the one hand and the provisions contained in this section or issued pursuant to this article on the other hand.

The effect and scope of the prohibitions and exceptions of article 85 , especially the interrelation between articles 85(2), 85(3), and 87, became the subject of a widespread and bitter controversy among spokesmen for various interest groups and scholars ${ }^{5}$ and resulted in sharply opposed national positions. Consequently, the preparation of the regulations envisaged and required by article 87 confronted the Commission and the Council of Ministers with a most difficult and delicate task which necessitated protracted deliberations and which, with the aid of the European Parliament and other advisory bodies, culminated in an intricate and ingenious solution of the complex problems. ${ }^{.}$In view of the extent of the issues to be settled, however, only a partial disposition of the whole subject could be achieved.

One of the most perplexing and debated issues concerned the legal effect of the prohibitions contained in article 85(1) and of the declaration of the nullity of arrangements in contravention thereto, contained in article $85(2)$. Were they automatically and immediately applicable and part of the national legal systems, even prior to the issuance of regulations to that effect, or was the illegality of the restraints proscribed by article $85(1)$ operative only after the intervention of a specific order of the Commission or the national authorities under articles 88 and $89(2)$ or upon the issuance of the regulations contemplated by article 87 ? This issue was argued extensively in the literature and arose also in several litigations pending in the national

5 For a survey of the issues in dispute and the literature on the subject see Riesenfeld, op. cit. supra note 1 , at 330-34.

${ }^{6}$ For details see Deringer, Die erste Durchführungsverordnung zu den Artikeln 85 und 86 des EWG-Vertrages, 12 WIRTSCHAFT UND WETTBEWERB [hereinafter cited as WuW] 84 (1962); Van Hecke and Suetens, op. cil. supra note 3, at 362. 
courts. One case, Bosch \& van Rijn v. de Geus, ${ }^{7}$ was finally brought before the Court of Justice of the European Communities and decided on April 6, 1962 , less than two months after the issuance of the regulations. The Court took notice of the regulations and, in fact, incorporated the first authoritative comments thereon in its opinion. The Bosch case concerned the validity and enforceability of exclusive national franchises granted by the Gernian firm Robert Bosch, G.m.b.H., to different distributors in various Commumity countries, among them to co-plaintiff van Rijn. Defendant, who was sued in tort for having disregarded the rights of the co-plaintiffs under the marketing scheme, contested the validity of exclusive franchises as contravening the EEC Treaty and the Court of Appeal of The Hague submitted the question to the Court of Justice of the European Communities for decision pursuant to article 177 of the EEC Treaty. ${ }^{8}$ The Court held that prior to the date on which the First Regulations For the Application of Articles 85 and 86 (hereinafter referred to as the regulations) went into effect, ${ }^{9}$ and absent any intervention by the local authorities under article 88 or by the Commission under article 89 , the agreements and decisions proscribed by article $85(1)$ were not automatically null and void. It concluded further that the status of existing restraints after that date had to be determined on the basis of the intricate system of validity, provisional validity, and limited retroactive nullity established by the regulations with respect to existing restrictive arrangenients.

Space forbids discussing in detail the regine for restrictive practices set up by the regulations. However, a brief résumé seems to be in order:

(a) The principal provision of the regulation is contained in article 1 which declares that "the agreements, decisions, and practices envisaged in article $85(1)$ of the Treaty and the abusive exploitation of the market within the meaning of article 86 are prohibited without a specific decree to that effect, except as otherwise provided in articles 6,7 , and 23 of the regulations."

(b) A large portion of the regulation centers around the declarations of the nonapplicability of article 85(1) (hereinafter referred to as certificates of harmlessness $\left.{ }^{\theta^{a}}\right)$ to particular types of restrictive arrangements

7 Cour de Justice des Communautés Européennes, April 6, 1962, 8 Rec. de la jurisprudence de la Cour 89. For a discussion of the decision, see Thompson, The Bosch Case, 11 INT's \& CoMP. L.Q. 721 (1962).

8 Article 177 provides for certification of questions involving the interpretation of the treaty by the national courts to the Court of Justice. The Bosch decision discussed at great length the jurisdictional implications of this provision.

${ }^{9}$ I.e., March 13, 1962 (20 days after publication in the Official Gazette which occurred on Feb. 21, 1962).

96 The certificate of harmlessness, i.e., the declaration provided for by art. 85(3), must be 
deemed to be salutary, as specified in article 85(3) of the treaty. Jurisdiction to grant these certificates is reserved exclusively to the Brussels Commission, ${ }^{10}$ but in order to regulate the issuance thereof and to protect the Commission from being inundated with applications under article 85(3) relative to minor restraints, a carefully designed system of notification, differentiating between new arrangements and existing arrangements, is devised in articles 4-7 of the regulations.

(c) Article 4 provides that new restrictive arrangements, falling under article 85(1) of the treaty, for which the parties desire to seek a certificate of harmlessness, must be notified to the Commission. In order to enforce prompt compliance, the regulations specify that no certificate may be issued without prior notification ${ }^{11}$ and that the exemption from the prohibition of article 85(1) flowing from such certificate may not antedate the day of filing. 12

The duty of notification and the sanctions for failure of timely compliance, however, are rendered inapplicable to certain categories of restrictive arrangements deemed to be capable only of minor harm to competition. ${ }^{13}$ These categories are enumerated in article 4(2) of the regulations and defined as agreements, decisions, and practices:

(1) that are participated in only by enterprises belonging to a single mem ber state and which do not concern the export or import between member states;

(2) that are participated in by only two enterprises and which have no other effect than

(a) restricting one party to such agreement in its freedom of determining the price or contractual terms with respect to the resale of goods that it has acquired from the other party to the agreement,

(b) imposing restrictions on the assignees or users of industrial property rights-especially of patents, utility models, design patents, or trade marks-or on the recipients of transfers or concessions of manufacturing processes or know-how pertaining to the utilization and application of industrial techniques in the exercise of such rights;

(3) that have as their object solely

(a) the elaboration or uniform application of norms and standards,

(b) common research in technological improvements, if the results are accessible to all parties and each of them may exploit them.

sharply distinguished from the "negative clearance," introduced by the regulations, art. 2. Negative clearance is granted if the Commission finds that the facts communicated to it reveal no reasons for intervention. For details, see Practical Gnide, op. cit. supra note 3, at pts. 2, II and 3, VII.

10 Regulations, art. 9.

11 Regulations, arts. 4(1), 6(1).

12 Regulations, art. 5(1).

13 Regulations, arts. 4(2), 5(2). 
(d) An analogous scheme is established for existing restrictive practices. The regulations envisage that such arrangements may still benefit from the issuance of a certificate of harmlessness provided that they were notified to the Commission prior to August 1, 1962, unless they belong to the potentially less harmful types specified in article $4(2) \cdot{ }^{14}$ In the latter case the issuance of a certificate of harmlessness is not dependent on any notification prior to a specified date. Nevertheless, even the existing restrictive agreements of the privileged types enumerated in article 4(2) must be notified prior to January 1, 1964, in order to benefit from the immunity accorded by article 7 against retroactive illegality that would otherwise intervene if the certificate of harmlessness were ultimately denied. The details will be discussed under (e).

(e) If the certificate of harmlessness provided for by article 85(3) of the treaty is ultimately denied, the restrictive agreements affected thereby might be deemed to be illegal with retroactive effect. In order to alleviate the rigors of such a rule, article 7 of the regulations contains specific provisions applicable only to restrictive agreements existing on the date when the regulations went into effect. If such agreements were notified to the Commission prior to August 1, 1962, if not belonging to the enumerated potentially less harmful classes, or are notified prior to January 1, 1964, if belonging to such classes, they may remain exempt from the prohibition of article 85(1) despite the unavailability of a certificate of harmlessness, provided they are modified so as henceforth to be outside the prohibition of article 85(1), or be entitled to a certificate of harmlessness. ${ }^{15}$

(f) The remaining provisions of the regulations deal with pecuniary sanctions, the conduct of proceedings and investigations, the cooperation between the Commission and national authorities, and other matters of a primarily procedural character.

As can be seen from this résumé, the regulations are silent about the relation between the national antitrust laws, on the one hand, and the rules for the protection of competition established by the EEC Treaty and the regulations, on the other, a subject which unquestionably possesses some of the most perplexing facets of the whole structure. ${ }^{16}$ To be sure, since the provisions of the EEC Treaty apply only to restraints with adverse effects on inter-member state commerce, restraints with purely domestic effects are not directly affected by the supranational regime. But this rule does not

14 Regulations, arts. 6(1), (2).

15 The regime of arts. 5 and 7 is discussed at length in the Bosch case mentioned in the text accompanying note 7 supra.

16 Compare the comments on this set of problems by van Hecke and Suetens, op. cit. supra note 3 , at 363 . 
solve the many problems that arise therefrom. For example, may a French or German firm participate with impunity in an agreement affecting intermember state commerce which is either outside the prohibitions of article 85 (1) or sanctioned by a certificate of harmlessness under article 85(3), although the nature of the agreement flouts the prohibitions of, and is not approvable under, the national laws for the control of anti-competitive practices? Conversely, is it proper to conclude that a firm will be liable under local law for a purely domestic restraint, although no responsibility would be entailed if it had engaged in a practice of the same type but of a dimension exceeding the national boundaries? Is it possible to argue, in order to escape the horns of this dilemma, that the ratification of the EEC Treaty constitutes an automatic repeal of all restraints that are stricter than the system adopted by the treaty?

An American enterprise may also be trapped in this puzzling situation. Assume, e.g., that an American manufacturer distributes its products by supplying one firm in each Community country. If the national distributor is a wholly-owned subsidiary it is hikely that the manufacturer and its national distributor subsidiaries will be considered as one enterprise and that any binding intra-enterprise allocation of markets by national boundaries and determination of pricing practices will be regarded as being outside the pale of the protection of competition by the EEC Treaty provisions. ${ }^{17}$ The reach of national laws, however, is met when such national subsidiaries enter into resale price maintenance agreements with subdistributors within a national territory. Conversely, if the exclusive national distributors are independent firms, the stipulations in the national franchises may well fall within the area of the practices prohibited by article 85 (1) of the treaty. Accordingly, they would certainly be subject to prompt notification under the regulations, if not totally incapable of being sanctioned under article $85(3) .{ }^{18}$ Moreover, the compatibility of such franchises with the national antitrust laws needs serious consideration.

In addition, the liability in damages for violation of the provisions of the EEC Treaty, as well as of the national antitrust laws, depends entirely on national legislation..$^{19}$ Finally, national views and approaches are bound to be reflected in the crystallization of the Community system. Hence, the national antitrust laws of the Community countries and their current developments are by no means of merely academic interest.

17 This is, indeed, the position taken by the German Bundeskartellamt in its last annual report, Bericht des BundesKarteltaMTES ÜBER SEINE TÄTIGKeIT IM JAHRE 1961, Deutscher Bundestag, Drucksache IV/378, 4 Wahlperiode 60, 61 (1962).

18 That is clearly the import of the Bosch decision, supra note 7.

19 See the discussion by Riesenfeld, op. cit. supra note 1, passim. 


\section{B. Background and Principal Sources of the National Laws Against Anti-Competitive Practices}

Legislative measures against restrictive practices exist in some form or other in all of the six Community countries. ${ }^{20}$ But in two of them, Italy and Luxemburg, no special machinery has been established, while the principal legal curbs are enshrined in some rather limited penal provisions against fraudulent maneuvers designed to affect the price level ${ }^{21}$ and in some general principles rendering concerted boycotts illegal and tortious. ${ }^{22}$

On the other hand, the four remaining Community nations have come to take a more particularized approach and have enacted specific legislation (coupled with the establishment of the necessary enforcement apparatus) designed to afford more systematic protection against restrictive or otherwise anti-competitive practices.

The chief enactments in that respect are: (1) in France: the Ordinance No. 45-1483 of June $30,1945,{ }^{23}$ "concerning prices," as amended by numerous sequels, especially the decree No. 53-704 of August 9, 1953, 24 "relative to the maintenance or re-establishment of free competition in industry and commerce" and the decree No. 58-545 of June 24, 1958, "for the modification of certain provisions of the ordinance of June 30, 1945"; 20 (2) in Germany: "Law Against Restraints of Competition" of July 27, $1957 ;^{27}$ (3) in The Netherlands: "Economic Competition Act" of June 28, 1956/July 16, 1958;28 (4) in Belgium: "Law Against the Abuse of Economic Power" of May 27, 1960.29

20 For a detailed survey of the development of the law in the Community countries until 1960 see Riesenfeld, op. cit. supra note 1.

21. Italy: Codice Penate art. 501 (1930). Luxemburg: Code de la Législation Pénate art. 311 (1 Hammes ed. 1953); Decree on Unfair Competition, Jan. 15, 1936, as amended, Code de ra Législation Pénade (2 Hammes ed., sub voce, Concurrence Déloyale 2, 1953).

22 Grisoli, Rapport sur le boycottage en droit italien, 10 TrAvaUX DE I'Association HENRI CaptTant pour la Culture JurmiQue Francaise 171 (1959); Huss, Rapport sur le boycottage en droit luxembourgeois, id. at 176.

23 [1945] Journal Officiel [hereinafter cited as J.0.] 4150; [1945] Sirey Lois Annotées 1898.

24 [1953] J.O. 7045; [1953] Bulletin Législatif Dalloz 587.

25 [1958] J.0. 5877; [1958] Bulletin Législatif Dalloz 447.

26 For details and a translation into English, see Riesenfeld, The Legal Protection of Competition in France, 48 CaLIF. L. Rev. 574 (1960).

27 [1957] I Bundesgesetzblatt 1081. For details see Riesenfeld, op. cit. supra note 1, at 216; Schapiro, The German Law Against Restraints of Competition-Contparative \& International Aspects (pts. 1-2), 62 ColvM. L. Rev. 1, 201 (1962).

28 [1956] Staatsblad van het Koninkrijk der Nederlanden [hereinafter cited as Stb.] 401; [1958] Stb. 412; combimed text printed in [1958] Stb. 413. For details see Riesenfeld, op. cit. supra note 1 , at 261.

29 [1960] Moniteur Belge 4674; reprinted in $10 \mathrm{WvW} 704$ (1960). For details see del Marmol \& Fontaine, Protection Against the Abuse of Economic Power in Belgium: The Lay of May 27, 1960, 109 U. PA. L. REV. 922 (1961). 
Of course, measures of this type, comprehensive as they may be, are not completely self-contained, but are complemented and supplemented by other special or general provisions in the national codes and statutes. ${ }^{30}$ In fact, the interrelation of the various provisions often presents the most baffling problems.

The existing laws must not be thought of as a sudden and complete break with the past. Actually they constitute the culmination of a development which dates back to the 20's. In 1923 Germany adopted the first legislation in Europe specifically designed to curb restrictive practices by cartels and monopolies, the famous "Ordinance Against Abuse of Economic Power." 31 The Netherlands passed legislation permitting the administrative dissolution of cartels in $1935 .^{32}$ France did not go quite so far at that time. But, in 1926, article 419 of the Penal Code-originally enacted in 1810 - was amended so as to penalize tampering with the price level of commodities, through individual or concerted action on the market, for the purpose of making a profit not resulting from the natural play of demand and supply.

Naturally, the divergence of the backgrounds of the legal systems as well as the variance in economic structure and policies in the various countries has made for a pronounced diversity of the local legislations against anti-competitive practices.

Let us now turn to the individual countries.

\section{II}

LAWS OF THE INDIVIDUAL COUNTRIES

\section{A. France}

\section{Scope and Types of Prohibited Anti-Competitive Practices}

As mentioned before, the core of the current French statutory provisions curbing anti-competitive practices is contained in articles 37 and 58 bis, ter and quater of the Ordinance No. 45-1483 (the so-called Price Ordinance), as amended.

a. Article 37 is directed primarily against vertical restraints and proscribes, inter alia, four important general types of conduct: (1) unjustified

30 E.g., France: Code PÉNAL art. 419 (crime of distortion of the price level) ; Code CIVII arts. 1382-86 (general provisions relating to liability in tort); CODE D'INSTRUCTION CranINELIE art. 2 (relating to the right to damages of victims of crimes). Germany: BüRGERLICAES GESETzBuCE $\S 138$ (nullity of transactions violative of the standards of fairness and decency) and $\$ \S 823,826$ (liability for tortious conduct).

31 [1923] I Reichsgesetzblatt 1067. For details, see Riesenfeld, op. cit. supra note 1, at 208.

32 Entrepreneurs' Agreemeuts Act of 1935 art. 6, [1935] Stb. 310, NEDERLANDScHe WETBOEKEN 2693 (Fruin 1959); discussed in Riesenfeld, op. cit. supra note 1, at 254. 
refusal to sell or render services; ${ }^{33}$ (2) habitual discrimination in sales terms or prices not justified by cost factors; $;^{34}(3)$ tying clauses $;^{35}$ and (4) imposition of minimum resale prices. ${ }^{36}$

b. Article 59 bis, conversely, is concerned with horizontal restraints and contains a general prohibition of concerted actions, agreements, expressed or implied, or coalitions that have as their object or may have as their effect the restriction of competition. Article 59 ter, however, permits an exception for cartel agreements that have the effect of improving or extending the outlets of production, or of assuring the development of economic progress by way of rationalization or specialization.

In addition to the regular courts and the district attorneys, the application of the suppression of anti-competitive practices under the Price Ordinance is entrusted to two special administrative agencies. The Direction Genérale des Prix et des Enquêtes Economiques is chiefly in charge of the application of article 37, while the enforcement of articles 59 bis, ter, and quater relies mainly on the investigatory and advisory activities of a special admimistrative tribunal, the Commission Technique des Ententes.

\section{The Application of Articles 59 bis and ter and the Work of the Commis. sion Technique des Ententes}

The Commission Technique des Ententes, either on its own motion or on request of the Minister of Economics, investigates whether certain sectors of the French economy are subject to concerted restrictive practices as defined in article 59 bis and, in case such practices are discovered, whether the exemptions of article 59 ter are applicable. The Commission reports its findings, conclusions, and recommendations for relief to the Minister of Economic Affairs, who decides what further action is indicated. Pursuant to a decree of $1959,{ }^{37}$ which provided for the publication of annual reports including the opinions of the Conmission and the decisions of the Minister, four reports covermg the activities during 1954-1955, 1956, 1957, and 1958-1959 have appeared in print. ${ }^{38}$

During that period the Commission rendered twenty formal opinions. In two of them the Commission found the absence of a horizontal agreement of the type envisaged by article 59 bis. In the other eighteen opinions

33 Price Ordinance art. 37 (1) (a).

34 Ibid.

35 Price Ordinance art. 37 (1) (c).

36 Price Ordinance art. 37 (4).

37 Decree No. 59-1004 of Aug. 17, 1959, [1959] J.0. 8507; [1959] Recueil Dalloz [hereinafter cited as D.] Législation 574.

38 [1960] J.O., Documents administratifs Nos. 1, 2, 11; [1961] J.0., Documents administratifs No. 12. 
the Commission exhibited a considerable degree of patience, if not leniency, vis-à-vis the cartels under investigation. In seven cases the Commission held that the justifying conditions of article 59 ter were met; in one further opinion the Commission found that the application of this article was at least temporarily warranted; and in another case the Commission recommended the granting of a probationary period to comply with the justifying conditions of article $59 \mathrm{ter}$. Even in the remaining nine cases, where a violation of article 59 bis was held to be present, the Commission refrained from recommending the imposition of drastic sanctions. In the course of its work the Commission developed a method for establishing an economic balance sheet relative to the organization in question in order to ascertain whether it was a good or a bad cartel. ${ }^{39}$

\section{The Application of Article 37 (1) and (4)}

As lias been stated before, ${ }^{40}$ article 37 is directed primarily against anticompetitive practices of the vertical type and proscribes four general classes of such practices, designated in American nomenclature as: (a) unjustified refusals to deal; (b) price discriminations; (c) minimum resale price maintenance; and (d) tying clauses. Three of these classes (a-c), whicli were redefined by the decrees of 1953 and $1958,{ }^{41}$ form the subject of detailed and important administrative interpretation, issued as a "circular" on March 31, 1960..$^{42}$ While this circular, according to a recent decision of the Council of State of May 5, 1961, ${ }^{43}$ has not the character of a regulation, but merely that of an imterpretation without binding effect, it nevertheless is of considerable practical importance. ${ }^{44}$

The various provisions against anti-competitive practices have been before the courts several times, in recent years. Generally speaking, the courts have pursued a rather strict course in enforcing the prohibitions against vertical restraints. Thus, the Court of Cassation recently reversed

${ }^{30} \mathrm{Cf}$. in this connection the discussion of the reports of the Commission Techmique des Ententes by Plaisant and Lassier, [1960] D. Chron. 61 and [1962] D. Chron. 31.

40 Text accompanying note 33 supra.

41 Text accompanying notes 24 and 25 supra.

42 [1960] J.0. 3048; [1960] Recueil Sirey, Lois Annotées 120.

43 Soc. Librairie Aristide Quillet et autres, Conseil d’État, May 5, 1961, [1961] Recueil des décisions du Conseil d'État 297, [1961] D. Jurisprudence 407.

44 The circular is divided into two main titles with the captions: "Probibition Against Fixing a Minimum Price" and "Measures Tending to Assure for All the Same Opportumities of Procurement." The latter title contains two main chapters dealing with "refusal to sell" and "discriminatory sales terms," respectively. The discussion of prohibited refusals to sell includes a lengthy section on exclusive franchises. According to the circular, exclusive franchises are exempt from the prohibition only if they provide for mutual restrictions and do not, directly or indirectly, impose restraints that are otherwise prohibited, especially resale price maintenance clauses. 
two decisions by courts of appeals which had taken a less stringent approach. In one case the Court of Cassation held that a manufacturer of trademarked cookies could not refuse to sell such cookies under their customary trade name and in their regular boxes to a retail consortium merely because, in the past, it had engaged in sales coupled with giveaways or sold merchandise at acquisition costs. ${ }^{45}$ In the other the court held that a manufacturer could not refuse the sale of certain radios to a department store where there was no proof that the sales on the retail level required technical expertise of the sales force. ${ }^{46}$

The question of how far article 37 affects the legality of exclusive dealerships has been the subject of special concern. The above mentioned circular devoted a lengthy discussion to that question, reaching the result that exclusive dealerships may be exempt from the prohibition against refusals to sell, but only if they meet a number of conditions, among them strict mutuality. In the case of Nicolas et Societe Brandt, ${ }^{47}$ the Court of Appeals of Paris held, however, that a sole distributor of a particular model of a camera could not lawfully create a network of exclusive dealerships for the merchandising of its product and was guilty of a violation of article 37(1) (a), if he refused to deal with other retailers. The court rejected the interpretation proposed in the circular of March 31, 1960, and adopted an even stricter view. The court dismissed a claim for damages by the injured party (Soc. Photo Radio Club), holding that it had to resort to a separate civil action.

Conversely, the courts have taken a more hberal approach vis-à-vis cartels. In Augé v. Etabl. Dorian-Holtzer, Jackson et Cie, et autres, ${ }^{48}$ the Court of Appeals of Lyon refused to declare a cartel among manufacturers of manual agricultural implements (hoe-maker cartel) to be illegal and remanded the matter to the court below for a more detailed market analysis by an expert.

Similarly, the Commercial Tribunal of Rouen ${ }^{49}$ held a division of customers between two common carriers to be legal and justified as an agreement for rationalization. ${ }^{50}$ But a concerted attempt of merchants to elimi-

45 Proc. gén. C. de cass., intérêt de la loi, aff. Barjolle, Cour de Cassation ( $\mathrm{Ch}$. crim.), July 13, 1961, [1961] D. Jurisprudence 525, reversing Cour d'Appel de Bordeaux.

46 Proc. gén. Lyon v. Colin et Soc. Radio-matériel, Cour de Cassation (Ch. crim.), July 13, 1961, [1961] D. Jurisprudence 531, reversing Cour d'Appel de Lyon.

47 Cour d'Appel de Paris, Feb. 7, 1961, [1961] D. Jurisprudence 175.

48 Cour d'Appel de Lyon, June 13, 1960, [1961] D. Jurisprudence 148.

49 Soc. de transit et transport G. Faroult v. Soc. de transit et transport J. Roy, Trib. Comm. Rouen, July 21, 1961, [1962] D. Sommaires 15.

$50 \mathrm{~A}$ term common in European antitrust legislation designed to describe measures to promote greater economic efficiency. 
nate a cheaper competitor from the market by interfering with his sources of supply has been held to be a violation of article 419 of the Penal Code, which entitles the victim to claim damages. ${ }^{51}$

The prohibition against fixing mimimum resale prices permits dispensation by joint order of the Minister of Commerce, the Minister for Economic Affairs, and other ministers having an interest in the subject matter ${ }^{52}$ Such exemption may be accorded especially for the exploitation of patented or otherwise guaranteed articles. But so far only about one hundred such requests have been granted.

\section{Special Legislation Against Preminems and Giveaways to Purchasers}

French law, like that of other European countries, includes a special prohibition against sales coupled with apparently free gifts. ${ }^{53}$ It supplements the provisions of article 37, dealing with tying-clauses, and has been before the courts quite often. ${ }^{54}$

\section{B. Germany}

\section{General Characteristics of the Law Against Restraints of Competition}

The German Law Against Restraints of Competition of July 27, 1957, ${ }^{55}$ constitutes a much more detailed and complex regulation of horizontal and vertical anti-competitive practices than the comparable laws of the other community countries. It is composed of 109 sections and was the result of a long legislative battle and, in a way, an ultimate compromise. ${ }^{56}$

The core of the statute consists of two prohibitions, one (section 1) directed chiefly against horizontal restraints, ${ }^{57}$ the other (section 15 ) out-

51 André et Leprête v. Chauvelot, Défaut et Mougin, Cour d'Appel de Nancy (Ch. corr.), Dec. 8, 1960, [1961] D. Sommaires 39.

62 Price Ordinance art. $37(4)$.

${ }^{53}$ Law No. 51-356 of March 20, 1951, [1951] J.0. 2980; [1951] D. Législation 89. Decree No. 61-861 of Aug. 5, 1961 implements and regulates in detail the application of the statute of 1951. [1961] J.O. 7331; [1961] Dall. Bull. Lég. 533.

64 For apphication see Dame God, Cour de Cassation (Ch. crim.), July 12, 1961, [1961] D. Sommaires 98.

55 [1957] I Bundesgesetzblatt 1081. [Hereinafter cited as Restraints of Competition Law].

56 For details see Riesenfeld, The Protection of Competition, in 2 Adrertcan ENTERPrISE In the European Comaron Market: A Legal Profile 197, 216 (1960). A reform proposed by the federal Ministry of Justice is presently being studied by the German Parliament.

57 "Agreements between enterprises or associations of enterprises, concluded for the accomplishment of a common purpose, and resolutions of associations of enterprises are invalid to the extent that they are apt to affect the production or the market conditions for the commerce in goods or occupational services by means of restraints on competition. This does not apply where this Law provides otherwise." 
lawing primarily vertical restraints. ${ }^{58}$ But both of these sweeping proscriptions are riddled with exceptions, qualifications, and limitations which make the resulting picture somewhat involved.

The exemptions from section 1 fall into two main categories:

(a) Cartel types that are deemed innocuous, unless particular clauses or conditions render them oppressive. The law defines five kinds of permissible cartels of this type: (1) export cartels; $;^{50}$ (2) quotation cartels; ${ }^{00}$ (3) conditions cartels; ${ }^{01}$ (4) rebate cartels; $;^{62}$ and (5) standardization cartels. ${ }^{83}$ Cartel agreements of this type must be filed with the Bundeskartellamt (BKA), the central agency in charge of the application and enforcement of the act, or with the appropriate local authorities. In all except one of these classes (quotations cartels) such filing is a prerequisite for the validity of the agreement. The cartel authorities may raise objections to particular agreements belonging to these five classes and thereby deprive them of their exempt status.

(b) Cartel types that may be beneficial under particular conditions and therefore need prior authorization for their legality. The law enumerates six kinds of such agreements: (1) structural crises cartels; ${ }^{04}$ (2) simple rationalization cartels; ${ }^{65}$ (3) rationalization cartels of higher order; $;^{00}$ (4) export cartels affecting the domestic market; ${ }^{07}$ (5) import cartels; ${ }^{\text {og }}$ and (6) emergency cartels. ${ }^{60}$

The prohibition against vertical restraints is likewise subject both to numerous qualifications and certain extensions. On the one hand, the law accords permission for: (a) resale price maintenance for trademarked and branded goods, provided that the agreements are properly filed; ${ }^{70}$ and (b) specified restraints stipulated in connection with the transfer or licensing of patents, utility models, and exclusive rights in brands, or other limitatations expressly authorized by the BKA. ${ }^{71}$

58 "Agreements between enterprises with respect to goods or occupational services which apply to domestic markets are void to the extent that they restrict one of the parties thereto in its freedom to determine prices or other terms in the contracts which such party may conclude with third parties in regard to the goods so supplied, other goods or occupational services."

59 Restraints of Competition Law $\S 6$ (1).

60 Restraints of Competition Law $\$ 5$ (4).

61 Restraints of Competition Law \$ 2 (1).

62 Restraints of Competition Law $\$ 3$ (1).

03 Restraints of Competition Law $\$ 5$ (1).

64 Restraints of Competition Law $\$ 4$.

65 Restraints of Competition Law $\$ 5$ (2).

${ }^{66}$ Restraints of Competition Law \& 5 (3).

67 Restraints of Competition Law $\S 6$ (2).

68 Restraints of Competition Law $\S 7$.

60 Restraints of Competition Law $\$ 8$.

70 Restraints of Competition Law $\S 16$.

71 Restraints of Competition Law $\$ 20$. 
On the other hand, the law provides for intervention by the federal or state cartel authorities in four types of vertical restraints not included within the general prohibition of section 15, if such restraints have specified adverse effects on the market. ${ }^{72}$ The four types considered as possible excesses are: (a) use restrictions; (b) resale restrictions; (c) exclusive dealing clauses; and (d) tying clauses.

In appropriate circumstances the cartel authorities may issue cease and desist orders and cancel the offensive restraints. ${ }^{73}$

Time and space forbid going into further details but it may be stated as a generalization that the German law is considerably more indulgent toward vertical restraints than the French law, but slightly stricter on the subject of cartels.

\section{Abuse of Dominant Market Power}

Unlike the American law, which in section 2 of the Sherman Act $^{74}$ and section 7 of the Clayton Act $^{75}$ has fashioned special weapons against monopolization and excessive concentration, the European antitrust laws have no effective provisions curbing excessive concentration. The German law has remained content with a duty to notify the cartel authorities of further concentrations, if one of the participating enterprises or the resulting enterprise controls twenty per cent or more of the market. ${ }^{76}$ By special statute of December 31, 1960, ${ }^{77}$ the federal legislature provided for an official investigation into the extent of concentration in the German economy, but because of political pressures the conduct of the inquiry was not placed into the charge of the energetic Federal Cartel Office but into that of the Federal Agency for the Furtherance of Trade (Bundesamt für gewerbliche Wirtschaft).

However, the Restraints of Competition Law, following in that respect its predecessor of 1923, subjects individual enterprises or groups of enterprises possessing dominant market power to a special abuse control. ${ }^{78}$ If the dominant power is abused by engaging in oppressive practices regarding the price or other terms of transactions or in unwarranted tie-ins, the cartel authorities may issue cease and desist orders and cancel the oppressive clauses or contracts.

72 Restraints of Competition Law $\S 18(1),(2)$.

73 Ibid.

7426 Stat. 209 (1890), as amended, 15 U.S.C. $\$ 2$ (1958).

7538 Stat. 730 (1940), as amended, 15 U.S.C. $\S 18$ (1958).

78 Restraints of Competition Law $\$ 23$.

77 [1961] I Bundesgesetzblatt 9.

78 Restraints of Competition Law $\$ 22$. 


\section{Other Types of Proscribed Restraints}

The prohibitions of the law are rounded out by special provisions against coercive practices against outsiders or non-conformists, ${ }^{70}$ secondary boycotts of competitors, ${ }^{80}$ and the use of the economic power possessed by enterprises with dominant market power, cartels, and enterprises engaged in resale price maintenance, for the purpose of oppressing or discriminating against other enterprises. ${ }^{81}$

\section{Practical Experience}

As indicated before, the administration and enforcement of the act is mainly in the hands of a special Federal Cartel Office which functions under the general supervision of the Minister of Economics. Certain decisions are reserved to the latter. In addition, the application of the law in cases having only a local character are left to the cartel authorities of the individual states.

The annual reports of the Federal Cartel Office regarding its activities contain illuminating information on the work load and the problems created by the law and the extent of disclosed or suspected restraints. ${ }^{82}$

\section{The Netherlands}

\section{General Characteristics and Scope of the Economic Competition Act of $1956 / 1958$}

The present Dutch statute is the third general enactment dealing with the subject of cartels and abuses of market power. The first law of this type

79 Restraints of Competition Law $\$ 25$.

80 Restraints of Competition Law \$26(1).

81 Restraints of Competition Law \$26(2).

82 During 1961, the federal and local cartel authorities received 215 notifications or applications for authorization under $\S \S 2-7$, sanctioning cartels for certain purposes or under certain conditions. During the same period, the cartel authorities conducted 740 proceedings because of suspected violations of $\S 1$ on the federal level and 790 such proceedings on the local level (counting only once the proceedings that were subsequently transferred from the federal office to the local authorities or vice versa). 155 resulted in fines. The total number of prosecutions against suspected violations of the act of all types anounted to 1,829 in the federal office and 1,356 before the local authorities. In addition, the federal and state cartel authorities conducted 834 proceedings for the issuance of cease and desist orders agamst suspected abuses. The number of trademarked articles for which current price maintenance notifications were on record totalled 198,059 (of which 87,196 belonged in the motor vehicle industry). Applications for authorization of restrictive clauses in licensing agreements amounted to 116. In 50 instances the authorization was granted. BERTCHT DES BUNDESKARTELIAMTTES ÜBER SEINE TÄTIGreit IM Jakre 1961, Deutscher Bundestag, Drucksache IV/378, 4 Wahlperiode (1962), especially tables $A, D, E, J, M$, and $N$. 
was the Entrepreneurs' Agreements Act of $1935 .{ }^{83}$ It was superseded by the Cartel Ordinance of 1941, issued under the aegis of the German Occupation Authorities. ${ }^{84}$

Generally speaking, the former Dutch legislation relied on registration and suppression of abuses rather than on outright prohibitions tempered by exceptions and dispensations. Moreover, Dutch law considered cartels as salutory if concluded to prevent disintegration of the industry and in such case provided for compulsory extension to outsiders.

Despite the tremendous growth of cartellization since 1950 the Dutch lawmakers chose to retain this general pattern. Accordingly the present Dutch statute ${ }^{85}$ focusses on four principal measures: (a) duty of registration and reduction to writing; ( b) compulsory extension of cartels to outsiders; (c) cancellation of restrictive agreements and resolutions to the extent that they are in conflict with the public interest; and (d) suppression of abuses of dominant market positions.

\section{Registration of Arrangements Regulating or Affecting Competition}

One of the central concepts of the new statute is that of "competition regulation," defined as agreements or resolutions, pursuant to private law, which constitute a regulation of competition among owners of enterprises. ${ }^{86}$ Without further action the statute applies only to legally enforceable arrangements of this type. The statute provides, however, that its applicability may be extended, by executive decree: (a) in toto to designated agreements and resolutions which merely affect competition; ${ }^{87}$ and (b) as far as apposite, to desiguated arrangements without binding character, whether regulating or merely affecting competition..$^{8}$

The application and enforcement of the act rests primarily with the

83 Entrepreneurs' Agreements Act of 1935, [1935] Stb. 310; NEDERLANDSCEE WETBOEKEN 2693 (Fruin 1959).

84 [1941] Verordnungsblatt fur die besetzten Niederländischen Gebiete 881. For details see Riesenfeld, op. cit. supra note 56, at 254.

85 Economic Competition Act, June 28, 1956/July 16, 1958 [hereinafter cited as Economic Competition Act], [1956] Stb. 401; [1958] Stb. 412; full text printed in [1958] Stb, 413.

80 Economic Competition Act art. 1(1). As can be deduced from the statutory phraseology and its legislative history, the concept of competition regulation is not restricted to horizontal contractual restraints but includes restraints of a vertical character. In a basic decision, involving the legality of an order of the Minister of Economic Affairs declaring a restrictive agreement between store owners in a shopping center in Rotterdam to be violative of the law and subject to cancellation, [1959] Nederlandse Staatscourant [heremafter cited as Stct.] No. 65, pp. 5-6, the Chamber for Competition Cases of the Appellate Court for Commerce and Industry held that the statutory definition required a broad and inclusive interpretation, 7 SoctaAl Econoartsche WeTgevIng 319 (1959).

87 Economic Competition Act art. 1(3).

88 Economic Competition Act art. 1(4). 
Minister of Economic Affairs, who is assisted therein by a special advisory board called the Economic Competition Commission. ${ }^{80}$

All competition regulations within the meaning of article $1(1)$ and all arrangements and resolutions which have been assimilated thereto by executive decree issued under article 1(3) and (4) must be communicated to the Minister of Economic Affairs. ${ }^{00}$ The contents of such communication must comply with particulars prescribed by administrative regulation. ${ }^{01}$ The Minister of Economic Affairs, alone or, if appropriate, in conjunction with other interested Ministers of State, may-by general regulation or special dispensation-establish exemptions from such requirement. ${ }^{22}$ The Minister has exercised this power and exempted various types of restrictive agreements from the requirement of communication. ${ }^{93}$

89 The composition of the Commission, which includes not less than twelve regular members, is governed by the Economic Competition Act article 28. Its internal organization and procedure are regulated by a Decree of Nov. 11, 1958, [1958] Stb. 489; reprinted in $11 \mathrm{WvW}$ 38 (1961). Decisions of the Minister are subject to judicial review. Economic Competition Act art. 33. The appeals are heard by a separate division of a special court, i.e., the Chamber for Competition Cases of the Appellate Court for Commerce and Industry. Economic Competition Act art. 35 in conjunction with art. 1(1).

Bo Economic Competition Act art. 2.

01 Decree of November 13, 1958, No. 33332, [1958] Stct. No. 221, p. 9 ; reprinted in 11 WuW 40 (1961).

92 Economic Competition Act art. 4.

${ }^{93}$ The current exemptions are specified in a Decree of June 3, 1960, No. 3908, [1960] Stct. No. 107, p. 9 ; reprinted in 11 WoW 44 (1961). They cover the following types of competition regulations:

(1) those that are not in force for more than one month except where they stipulate for express or implied extension;

(2) those concluded between one supphicr and one customer which determine the price at which the customer may resell the goods obtained from the supplier;

(3) those among retailers in milk, milk products, and special milk products, as defined in article 2, paragraph 1 of the Ordinance Establishing the Trade Organization of the Retail Trade in Milk and Milk-and-Dairy Products, [1955] Stb. 523, which aims at the rationalization of the local supply of these goods;

(4) those which regulate no other matters concerning competition except (a) the joint purchase of goods; (b) the obligation of a supplier to supply specified goods exclusivcly to one customer, whether within a defined territory or not; (c) the obligation of a customer to procure specified goods exclusively from one supplier, whether within a defined territory or not; (d) the obligation imposed upon a trader or agent to act exclusively as the representative of a simgle firm, either within a specified territory or in general; (e) the obhgation not to engage in a specified trade or business, whether within a defined territory or not, provided that sucb stipulations are part of a contract of employment or for the transfer of an enterprise which maintains such trade or business; (f) the production, marketing, or procurement of goods abroad or the rendition or utilization of services abroad; (g) international transportation, so far as such regulation of competition includes one or more natural or juristic persons having a foreign domicile;

(5) those which do not regulate economic competition withm the Netherlands. 
Failure to comply with the communication requirements is a misdemeanor. Moreover, agreements thus withheld may be declared to be unenforceable by administrative decree. ${ }^{94}$ It may be of interest to learn that as of January 1, 1961, the Register of Competition Regulations contained 856 entries of agreements with country-wide scope and 594 entries of regional and local regulations. ${ }^{95}$

\section{Invalidation of Competition Regulations Deemed To Be in Conflict With the Public Interest}

The present act provides for the termination or suspension, in whole or in part, of restrictive agreements and resolutions to the extent that they are deemed to conflict with the public interest. Such invalidation may be ordered either by means of general orders declaring the generic invalidation of certain classes and types of restrictive clauses in agreements or resolutions $^{96}$ or by individual order, issued after special proceedings, concerning a particular competition regulation. ${ }^{97}$

General invalidations affect both existing and future agreements and resolutions of the types specified in the general order, but lapse after five years. ${ }^{98}$ Issuance of orders of this type requires previous advice of the Economic Competition Commission, request for which must be published in the Nederlandse Staatscourant..$^{99}$ The act authorizes individual exemptions from such generic invalidation. ${ }^{100}$

Individual invalidation, in whole or in part, of particular competition regulations likewise requires an advisory opinion by the Economic Competition Commission, rendered after a hearing accorded to the affected and other interested parties. ${ }^{101}$ The opinions are also published in the Nederlandse Staatscourant.

The act purposely refrains from establishing precise tests for the determination of a conflict with the public interest and leaves the matter to the development of decisional law crystallized through a case-by-case approach. The guiding principles established by these precedents have been formulated and reformulated from time to time. A recent version is con-

94 Economic Competition Act arts. 5, 41(3).

95 Report of the Minister of Economic Affairs to the Dutch Parliament regarding the application of the Economic Competition Act during 1960, Proceedings of the Dutch Parliament, Sess. 1960-1961, Doc. No. 6348 (1961).

${ }^{86}$ Economic Competition Act arts. 10-15.

87 Economic Competition Act arts. 19-23.

08 Economic Competition Act art. 10.

${ }^{99}$ Economic Competition Act art. 11.

100 Economic Competition Act art. 12.

101 Economic Competition Act art. 20. 
tained in the second report by the Minister of Economic Affairs to the Dutch Parliament on the application of the act, covering the year $1960 .{ }^{102}$

\section{Suppression of Abuses of Dominant Market Positions}

Like the German law the Dutch act contains specific provisions designed to prevent abuses of a dominant market position where such abuses are not manifested in formal agreements and resolutions. For that purpose the Minister may issue four types of orders holding the enterprises affected to a particular course of action, ${ }^{103}$ viz. orders: (a) requiring abstention from coercive practices such as boycotts; (b) requiring the supply of goods or the rendition of services to designated persons at customary terms; (c) fixing prices for specified goods or services; (d) determining the terms of the sale of goods or services, including rules prohibiting resale restrictions or tying clauses. Issuance of such orders again must be preceded by consultation of the Economic Competition Commission. ${ }^{104}$

\section{Practical Experience}

Examination of the Staatscourant shows that the new law has not remained a dead letter and that a number of proceedings have been initiated, usually with the result of voluntary compliance. ${ }^{105}$

102 Note 95 supra. The report is discussed by Mok, Kartelbeleid in de afgelopen Jaren, 9 SociaAl Economische Wetgevinc 267, 269 (1961). The practices thought to be in conflict with the public interest were defined and distributed into five categories as follows:

(1) Impeding the activities of certain types of commercial organization such as cooperatives, joint purchase combinations, department stores, branch establishments, and horizontal or vertical enterprise groupings;

(2) Preventing the direct supply or procurement of goods by the elimination of certain commercial middlemen;

(3) Conditioning the admission to a particular trade upon the fulfillment of requirements as to professional or business knowledge or as to financial responsibility which go beyond those now existing for the respective trades; making the admission to a trade dependent upon the approval by those who are members of an orginization established to regulate competition or upon a purported criterion of need; usmg vague and subjective admission standards like morality, reputation, etc.; setting admission requirements pertainimg to industrial equipment, turnover, capital, etc., at a higher level than is reasonable; making the admission requirements of the type mentioned for persons who apply for admission stricter than those met by persons who have already been admitted; lack of an orderly procedure and of an impartial appellate tribunal for decisions regarding such admission;

(4) Manipulating minimum prices so as to obstruct an economically warranted competition;

(5) Coercing the observance of competition regulations without sufficent guarantees for a proper administration of justice.

103 Economic Competition Act art. 24.

104 Economic Competition Act art. 26.

105 See, for example, [1961] Stct. No. 118, p. 11: exclusion of a wholesaler from supply with cigarettes constitutes the exploitation of a dominant market position in conflict with the 


\section{Belgium}

The most recent newcomer to the family of antitrust laws operating in the Community countries is the Belgian Law Against the Abuse of Economic Power of May 27, $1960 .{ }^{106}$ It is by far the most general and indulgent legislation of the four under discussion. It proceeds strictly on the abuse theory and contains neither registration requirements nor specific prohibitions.

The law provides (1) for informal imvestigatory proceedings conducted by a Commissioner for Investigations of Abuses of Economic Power, established at a special body, called Council for Economic Disputes, ${ }^{107}$ and (2) for formal investigations conducted by special trial divisions of that Council. ${ }^{108}$ If the Council, upon formal hearing, finds that an abuse of economic power is present it advises the Minister of Economics to that effect. If the Mimister accepts such finding he must attempt to obtain a discontinuance of the objectionable practices by an amicable recommendation of remedial action. ${ }^{109}$ If the parties persist in their practices the Minister may obtain a formal royal decree containing a cease and desist order. If a juristic person is a repeated offender additional sanctions may be imposed designed to curb existing or the acquisition of further economic power. ${ }^{110}$

Abuse of economic power is defined by a general formula, identifying it with the infliction of harm upon the public interest by means of practices

public interest which would have required a cease and desist order but for the voluntary compliance agreed upon by the guilty distributors; $i d$. No. 122, p. 7: notice of the illegal restraints found, as a result of an investigation, in certain portions of the competition regulations governing the trade in certain types of white and wrapping paper, and of the voluntary elimination of the objectionable features; id. No. 151, p. 4: order, based on Economic Competition Act article 24, directing twenty-eight enumerated cigar manufacturers to desist from the abuse of a dominant position in the market and to supply an excluded wholesale distributor with tobacco articles at the customary terms; id. No. 188, p. 1: notice of the request for advice from the Economic Competition Commission as to whether there exists an occasion for exercising the powers conferred by Economic Competition Act article 19 and for taking steps against the cigar cartel established in 1949; $i d$. No. 234, p. 6: notice of illegal restraints discovered, upon investigation, in the competition regulation for the bicycle trade and of the voluntary elimination of the objectionable features by the Central Bureau for the Bicycle Trade (an English translation of the full text of the notice is reproduced in the Appendix).

108 [1960] Moniteur Belge 4674; reprinted in 10 WuW 704 (1960).

107 Law Against the Abuse of Economic Power art. 5. According to information provided by the Minister of Economic Affairs and Energy in September, 1961, in reply to a written question by a member of the Belgian Parliament, there were at that time six complaints pending before the Commission. QUestrons et Réponses, ChaArbre des Represéntants 719 (1961).

108 Law Against the Abuse of Economic Power art. 9.

109 Law Against the Abuse of Economic Power art. 14.

110 Law Against the Abuse of Economic Power art. 15. 
which distort or restrict the normal play of competition or which hamper either the economic freedom of producers, distributors, or consumers or the development of production or trade.

\section{CONCLUSION}

The foregoing discussion demonstrates the divergence of approaches and policies that exists among the various antitrust legislations of the countries forming the European Economic Community. Forging these disparate components into a consistent and harmonious community system is indeed a task that will require great ingenuity, tolerance, and persistency on the part of the responsible agencies. Meanwhile, the American enterprise selecting its distribution system and location in the Common Market must not ignore the antitrust ramifications of its choice among the factors determining its ultimate decision.

\section{APPENDIX}

EXAMPLE OF INFORMATION, PERTAINING TO THE RESULTS OF AN INVESTIGATION OF RESTRICTIVE PRACTICES IN A PARTICULAR INDUSTRY, PUBLISHED IN THE NEDERLANDSE STAATSCOURANT

Competition Regulation By the Central Burean for the Bicycle Trade. Nov.30,1961 / No.K 6536 / Directorate General for Commerce and Industry

The Secretary of State for Economic Affairs,

Issues the following notice by virtue of article 45 , in conjunction with article 20(5), of the Economic Competition Act: An investigation was conducted as to whether the occasion existed for exercising the powers, conferred by the Economic Competition Act, of taking measures against the competition regulation (trade regulation within the meaning of the meanwhile repealed Cartel Ordinance) that is administered by the Central Bureau for the Bicycle Trade.

With respect to this regulation the then Minister for Public Trade Organizations requested advice from the Commission for Trade Regulation by means of a notice published in the Staatscourant (1956, No. 25).

The Central Bureau for the Bicycle Trade, which is formed by the manufacturers, importers, agents, wholesale distributors and retailers/repairmen, engaged in the bicycle trade, has instituted a regulation of the above-named branch of the economy. Within the framework of this regulation rules have been established for the admission and business methods that are supported by the economically exclusive character thereof.

The investigation has revealed that the regulation in question was in conflict with the promotion of the public interest in several respects, to wit:

1. The regulation did not provide for the possibility of recognizing enterprises which assemble bicycles and $-\mathrm{m}$ contrast to the manufacturers and importers-sell them directly to the public. 
At the same time the regulation did not permit that the financial advantages that flow from a voluntary affiliation between wholesalers and retailers are passed on to the latter.

Circumstances which are capable of justifying such restrictions against the abovenamed commercial practices have not appeared in the branch of the industry involved.

2. The granting of seasonal discounts to customers is barred. The granting of such discounts may facilitate the marketing of bicycles in the slack season, which may entail more uniform marketing and manufacturing and, consequently, a reduction of costs.

3. A wholesaler is required to charge a profit margin of at least ten per cent when he supphies a retail enterprise of his own. This rule constitutes too severe a restriction against the growth of integrated business organization.

4. Retailers and bicycle repairmen are obliged, by means of the publication of list prices for goods falling within the bicycle trade for which retail prices are not already prescribed by the manufacturer, importer, or wholesale distributor, to apply specified minimum profit margins. This obligation, without more, was unacceptable because of its price rigidifying nature. Retailers who are able to calculate lower profit margins consistent with an economically responsible conduct of their enterprises are prevented from being satisfied with those inargins.

5. The advertising of older models or damaged bicycles at reduced prices is restricted. In that way the retail inerchants are prevented from bringing price reductions to the attention of the public by means of advertising. No reasons appear to be present upon which such a restraint of competition in this branch could be justified.

6. Recognized enterprises are permitted to supply frames for delivery vans only to those builders of delivery cycles who are recognized as sellers of dehvery cycles.

The manufacture of vans for dehvery cycles has developed into a separate branch of industry. Since the competition regulation concedes in general that recognized forms of supply may be furnislied for purposes which fall within the scope of the bicycle trade, no bar may be imposed against supplying the above-mentioned frantes to all lawfully established builders of delivery cycles.

After the above-listed points were communicated to the Central Bureau for the Bicycle Trade the competition regulation was aniended in such fashion that for the present the objections raised are met to the full extent.

Therefore, there exists no occasion for taking measures against the competition regulation by reason of the Econormic Competition Act.

/s/ Gravenhage, Nov. 30, 1961

The Secretary of State for Economic Affairs 